\author{
Mehmet Akif Ersoy Üniversitesi Fen Bilimleri Enstitüsü Dergisi 12(1): 41-53 (2021) \\ The Journal of Graduate School of Natural and Applied Sciences of Mehmet Akif Ersoy University 12(1): 41-53 (2021)
}

Araştırma Makalesi / Research Paper

\title{
Konut Bahçelerinde Peyzaj Uygulamaları Üzerine Bir Çalışma: İzmir İli Kemalpaşa İlçesi Örneği
}

\author{
Candan KUŞ ŞAHIN (D) ${ }^{*}$, Humeyra ÇALIK ${ }^{D} 2$ \\ ${ }^{1}$ Süleyman Demirel Üniversitesi, Mimarlık Fakültesi, Isparta \\ ²üleyman Demirel Üniversitesi, Fen Bilimleri Enstitüsü, Isparta \\ Geliş Tarihi (Received): 25.01.2021, Kabul Tarihi (Accepted): 27.02.2021 \\ $\square$ Sorumlu Yazar (Corresponding author*): candansahin@sdu.edu.tr \\ (C) +902462118222 骂 +902462118231
}

ÖZ

Günümüzde insanların açık ve yeşil alanlara olan özlemlerini gidermek, doğayla olan ilişkilerini artırmak ve bunların yanı sıra konuta estetik ve fonksiyonel değer kazandırmak için konut bahçeleri oldukça önem kazanmıştır. Çalışmada, kentsel yeşil alanların en küçük birimlerinden birisini oluşturan siteler, İzmir ili sınırları içinde yer alan örnek bir özel konut projesinde irdelenmiştir. Bu bağlamda, İzmir ili Kemalpaşa ilçesi sınırları içinde yer alan yerleşim alanının 1. etabında bulunan toplam 26 adet müstakil konutta çalışma sürdürülmüştür. Çalışma alanındaki konut bahçelerindeki yapısal ve bitkisel uygulamalar, detaylı bir şekilde incelenmiştir. Araştırmada, konutların çevresinde bulunan ve konut kullanıcılarına ait olan bahçeler için, bölgenin doğal ve kültürel özellikleri dikkate alınarak peyzaj tasarım ilkeleri doğrultusunda projeler hazırlanmıştır. İnşaat alanındaki her bir konuta ait bahçe büyüklükleri farklılık göstermektedir. ÇaIışma alanı olarak belirlenen 1. etap konutlarında bahçe büyüklükleri, $250 \mathrm{~m}^{2}$ ile $850 \mathrm{~m}^{2}$ arasında değişiklik göstermektedir. Ayrıca konutlar arasında kod farklılıkları da bulunmaktadır. Her konutun projesi, birbirinden farklı olarak çizilmiş ve uygulaması yapılmıştır. Her bahçenin sınırları, güvenlik nedeniyle tel çitler ile çevrilmiş olup, uygun yerlerde bahçe giriş kapılarına yer verilmiştir. Her konutun kendisine ait bahçeden bağımsız otoparkı bulunmaktadır. Otoparkların ön kısımlarında tel çit ile sınırlama yapılmış olup, bahçelerin iç kısmında bitkilendirme yapılarak, bahçelerin iç kısımlarının görünmesi kısmen engellenmiştir.

Anahtar Kelimeler: Bahçe, İzmir, müstakil konut, peyzaj tasarımı, peyzaj uygulamaları

\section{A Study on Landscape Applications in Residential Gardens: The Case Study of Kemalpaşa District of Izmir Province, Turkey}

\begin{abstract}
Gardens have become important places for satisfying people's longing to increase their relationship with nature, with adding aesthetic and functional value to the residential houses. In this study, an exemplary private residential construction project located in borders of Kemalpaşa district of İzmir province, is examined. In this context, work has been carried out in a total of 26 detached houses located in the 1st stage of a private settlement project area. A project was prepared under the view of the landscape design principles, for the garden of detached houses which belong to the residents. The garden sizes of each house in the construction area are different from others. The garden sizes of the 1st phase residences determined as the study area vary between $250 \mathrm{~m}^{2}$ and $850 \mathrm{~m}^{2}$. There are also some elevation differences between residential places. Therefore, projects for each residential unit has been drawn and implemented differently. Wire fences for security reasons surround the borders of each houses and garden entrance doors are placed appropriate placers. Each residential unit has its own parking lot that is independent from the garden. It has also found that limitations were made with wire fences on the front parts of the car parks, and the interior parts of the gardens were partially prevented by planting.
\end{abstract}

Keywords: Garden, İzmir, detached house, landscape design, landscape applications 


\section{GíRiş}

Insanın temel gereksinimlerinden birisi olan konut, toplumsal sistem içinde en küçük barınma ortamıdır. Konut; sadece fiziksel bir yapı değil, karmaşık istekler ve ihtiyaçlar bütününün oluşturduğu yerleşmiş bir kurumdur. Bunun nedeni, konutun form ve mekan organizasyonunun ait olduğu kültürel çevre tarafından şekillendirilmesidir (Rapoport, 1969). Yapı ve işlevleri, içinde bulunduğu toplumun sosyo-kültürel düzeyi ile belirlenen, toplumun sosyo-ekonomik özelliklerini bünyesinde barındıran bir yapı olan konutun temel işlevi, insanı fiziksel etkilerden korumak ile birlikte düşünce ve davranış sistemlerinin başkalaşmasıyla farklı fonksiyonlar kazanmış ve dönüşümlere uğramıştır (Dülgeroğlu, 1995). Hayward (1975); konutun sadece barınak değil aynı zamanda ben kimliğinin yer aldığı sosyal ve kültürel bir birim olarak organizasyonsal sistemlerin karmaşık hiyerarşisinin bir parçası olduğunu belirtmektedir. Bu bağlamda konut; biyolojik bir varlık, bir nesne ve çevrenin bir parçası olarak insan gereksinmelerini karşılamakla beraber, ihtiyaç duyulan çevre koşullarını da sağlamak durumundadır (Lang, 1994). Günümüzde, insanların hayatının büyük bir kısmını geçirdiği, kendisini özgür, rahat ve güvende hissettiği, kişinin yaşam tarzını belirleyen sosyal bir olgu olan konut, yakın çevresinden bağımsız bir şekilde düşünülemez. Konut ve yakın çevresi, birbiriyle bütünleşmiş, üstlendikleri fonksiyonlar bakımından farklılaşan, birbirini tamamlayan iki kavramdır.

Günümüzde konut ve çevresinin fiziksel özellikleri, yaşam kalitesinin önemli göstergelerinden birisi olarak kabul edilmektedir. Çevresi iyi düzenlenmiş bir konut, yaşam kalitesini arttırmakta ve ailelerin komşuluk ilişkileri açısından etkileşim halinde olmalarına, bu sayede toplumsal bütünleşme sağlamalarına olanak sunmaktadır (Bayraktar ve Girgin, 2010). Konut çevresi, hem özel mekandan kamusal mekana geçişi sağlamakta hem de bireylerde kişilik ve kimlik oluşumunda etkili olmaktadır. Benzer şekilde bireylerin kişilik ve kimliği de konut çevresini etkilemektedir. Bunun nedeni; konut çevresinin, konut-sokak ilişkisi ve komşuluk kapsamında sosyal etkileşimin gerçekleştiği önemli mekanları içermesidir. Konut çevresi; bireyin kendi kimliği, grup kimliği ve sosyal roller açısından öğretici ve destekleyicidir (Gökçe, 2007). Yaşanılan konut ve çevresinin güvenli olması, bireylerin kendilerini ve ailelerini güvende hissetmeleri, konutun mahremiyetinin sağlanması, konut kullanıcılarının huzurlu olmasını sağlayarak memnuniyeti de arttırmaktadır (Baker, 2003). Ayrıca sosyal donatının yeterliliği ile bunlardan yararlanan kişiler arasında kurulacak sosyal ilişkiler, sosyal bütünleşmenin sağlanması, konut çevresindeki komşuluk bağları, konut memnuniyetinde etkili olabilmektedir (Amerigo ve Aragones, 1990; Türkoğlu, 1997; Fernandez ve ark., 2003).
İnsanların zamanının büyük bir kısmını geçirdiği, çeşitli zevkleri tattığı yer olan bahçe, kültür mirasının önemli bir bölümü, insan-doğa ilişkilerinin yansıtıcısı, ideal bir dünyanın tasarlandığı mekan olarak ifade edilmektedir. Bahçeler, insanların günlük yaşantılarındaki sıradanlıkları sonucu ortaya çıkan sıkıntılarından kurtularak, doğaya ait varlıklarla bir arada olabilecekleri bir tür sığınak haline gelmiştir (Gültekin, 1991; Akdoğan, 1995). Bahçenin en önemli özelliği, kullanıcıya sunduğu hayal gücünde sakIıdır (Conan, 2006). Bahçelerde, hangi kültüre ait olursa olsun hayal gücünün değerine rastlamak mümkündür. Genellikle ortak nokta, söz konusu hayallerin ve arayışların bahçe tasarımına yansıması olarak ortaya çıkmaktadır. Bahçeler, hayal gücü ve düşünce için ilham kaynağı mekanlar olmalarının yanı sıra, tasarımları da bu hayal gücünün ve düşünsel altyapının ürünleri olmuştur (Karaçizmeli, 2011).

Konutlarda insanların mutlu, rahat ve güvenli bir şekilde yaşayabilmeleri için, konutun olduğu kadar çevresinin de düzenlenmesi gerekmektedir. Günümüzde insanların azalan yeşil alanlara karşı duyulan özlemlerini gidermek, doğa ile olan ilişkilerini arttırmak, konutlara estetik değer kazandırmak için konut bahçeleri önem kazanmıştır (Taşkan, 2014). Konut kullanıcısının niteliklerini; yaş, eğitim düzeyi, cinsiyet, sosyo-ekonomik yapı, sosyo-kültürel yapı, beklentiler, deneyimler, yaşam tarzı ve dünya görüşü belirlemektedir. Aynı nitelikler konut bahçesi kullanıcısı için de geçerlidir. Her konut ve bahçesinin kullanıcısı farklı niteliktedir. Konut bahçeleri; farklı bir mekanda, farklı topoğrafik özelliklerde, farklı iklimsel özelliklerde, farklı toprak özelliklerindedir (Demirarslan, 2005; Kumbasar, 2008).

Ev ve bahçe planlamasında kullanım durumunun belirlenmesinde 4 ana fonksiyon dikkate alınmaktadır (Tanriverdi, 1975; ASLA, 1989; Korkut, 2002; Çetinkaya, 2016);

- Ön bahçe alanının (esas giriş alanının) planlanması: Ön bahçe; giriş kapısı, ön teras, yaya yolu ve taşıt yolunu içine almaktadır. Önceki dönemlerde ön bahçeler dış ortamdan; yüksek duvar, çit, ahşap veya demir parmaklıklarla çevrilirken, iç kısma bitkiler dikilerek tamamen içe dönük bir yaşama mekanı haline getirilirdi. Ancak günümüzde modern şehircilik anlayışına göre konutların ön bahçeleri tamamen caddeye açılmış, ön bahçe ile cadde bir bütün halinde planlanmaya başlamıştır. Bu bahçeler, kent peyzajına olumlu etki yapmaktadır. Ön bahçede; bahçe kapısı ile konut giriş kapısı sade, rahat bir yaya yolu ile bağlanırken, cadde ile giriş arasında da taşıt giriş yolu planlanmaktadır. 
- Çalışma ve servis alanının planlaması: Çalışma ve servis alanı; garaj, depo, çeşitli alet ve makineler, atölye, çocuk oyun alanı, kümes, mutfak, sebze bahçesi ve meyve bahçesini içine almaktadır. Güzel bir görünüme sahip olmayan bu elemanların ön ve arka bahçeden görünmesi istenmemektedir. Bu sebeple, söz konusu elemanlar ve kullanımlar, bahçenin yan kısmına yerleştirilmelidir ve çit ya da çalı gruplarıyla çevrilmelidir.

- Arka bahçe (genel yaşama alanı) planlanması: Oturma, dinlenme, yemek yeme, okuma, oyun-müzik odaları, teras, havuz gibi kısımları içine almaktadır. Bahçenin en renkli, en geniş, en güzel görüş ve görünüş alanına sahip olan bölümüdür. Teras; oturma, oyun alanı, pergola, havuz gibi kısımları içine almaktadır. Oturma odasından ve yemek odasından arka bahçe seyredilebilmeli, görüşü kapatacak kullanımlara özellikle orta bölümde yer verilmemelidir. Arka bahçede, vurgu ile dikkat çekecek bir ana görüş noktası bulunmalıdır.

- Özel yaşama alanı planlanması: Giyim odası, yatak odası, banyo ve dinlenme alanını içine almaktadır. Banyo ve yatak odaaı gibi özel iç yaşama mekânı, evin bahçe görünüşü ile en az ilgisi olan yerinde planlanmalıdır. Özel yaşama mekânı, çoğunlukla yan bahçede, dış görünüşe karşı kuşatılmış küçük bir alandır. Güneşlenme, gölge, dinlenme ve uyuma gibi fonksiyonları yerine getirmektedir.

Toplu konut alanlarında; spor alanları, çocuk oyun alanları, yollar, otoparklar ve yeşil alanlara düzenleme ilkeleri doğrultusunda yer verilmelidir. Tek konutlarla karşılaştırıldığında site ve toplu konutlarda, birlikte yapılmaktan doğan olumlu özellikler bulunmaktadır. Toplu konutların siteler oluşturarak, kentlerin düzenli ve planlı gelişmesine katkıda bulunması, konut arzındaki dengelenme ile yasal olmayan sağlıksız yapılaşmanın azalmasına yardımcı olmaktadır (Subaşı, 2000; Özdemir, 2006).

Kullanış yönünden başka bir yapı ile bağlantısı olmayan, bağımsız konut anlamına gelen müstakil konutlarda insanların daha rahat, mutlu ve güzel bir şekilde yaşayabilmeleri için konutun olduğu kadar çevresinin de düzenlenmesi gerekmektedir. Günümüzde insanların açık ve yeşil alanlara olan özlemlerini gidermek, doğayla olan ilişkilerini arttırmak ve bunların yanı sıra konuta estetik ve fonksiyonel değer kazandırmak için konut bahçeleri oldukça önem kazanmıştır. Bu amaç doğrultusunda, İzmir kenti Kemalpaşa ilçesinde örnek olarak seçilen özel bir konut uygulama 1. etapta bulunan toplam 26 adet müstakil konut özelinde çalışma sürdürülmüştür. Konutların çevresinde bulunan ve konut kullanıcılarına ait olan bahçeler için, bulundukları bölgenin doğal ve kültürel özellikleri dikkate alınarak peyzaj tasarım ilkeleri doğrultusunda projeleri hazırlanmıştır. Konut bahçelerinin kullanıcıları ile iş birliği halinde olunarak, çizilmiş olan projeler doğrultusunda alanda hem yapısal hem de bitkisel uygulamaları yapılarak, çalışma tamamlanmıştır.

\section{MATERYAL VE YÖNTEM}

Çalışmanın ana materyalini, İzmir iline bağlı Kemalpaşa ilçesinde özel bir konut inşaat projesi oluşturmaktadır (Şekil 1). Bu konut projesi 72 adet konut olarak, 1. ve 2. etaptan oluşmaktadır. Bu araştırmada, uygulaması devam eden konut projesinin tamamlanmış olan 26 konuttan oluşan 1. etap kısmı çalışma alanı olarak seçilmiştir.

İzmir kentinin doğusunda yer alan ilçenin kuzeyinde Manisa ili; güneyinde Torbalı ve Bayındır ilçeleri; doğusunda Turgutlu ilçesi; batısında Bornava ve Buca ilçeleri bulunmaktadır. Kemalpaşa ilçesinin eski adı Nif'dir. Şehre uzaklığı ise yeni Kemalpaşa çevre yolu bağlantısı üzerinden Bornova'ya 30 km uzaklıktadır. Araştırma materyali olan konut projesi bu mevkidedir.

Çalışma kapsamında; İzmir ilinin Kemalpaşa ilçesinde yer alan özel bir konut inşaat projesi kapsamında yapılan konutlarının bahçelerinin peyzaj mimarlığı açısından incelenmesi amaçlanmıştır. Bu bağlamda çalışma, altı aşamada yürütülmüştür:

1. Çalışmanın konusu ve amacının belirlenmesi,

2. Çalışma alanının belirlenmesi,

3. Literatür taraması,

4. Yöntemin belirlenmesi,

5. Çalışmaya ilişkin verilerin elde edilmesi,

6. Sonuç ve öneriler.

İlk olarak, konu ile ilgili yerli ve yabancı kaynaklar taranarak konunun kavramsal çatısı oluşturulmuştur. Konut bahçelerinin kullanıcıları ile iş birliği halinde olunarak, çizilmiş olan projeler doğrultusunda alanda hem yapısal hem de bitkisel peyzaj uygulamaları yapılarak, çalışma tamamlanmıştır. 

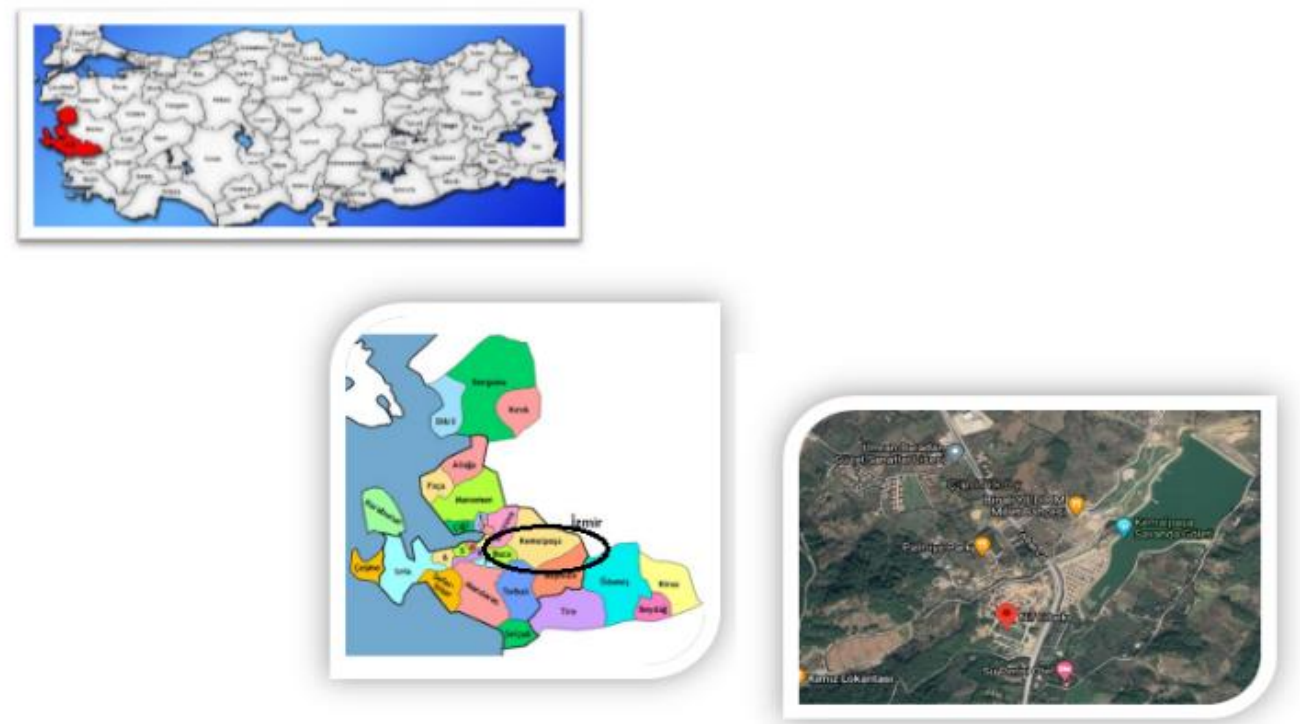

Şekil 1. Çalışma alanının konumu

\section{BULGULAR}

"Doğanın yaşanabilir hali” teması ile yola çıkılan proje, ormanın yanında, 100 dönümlük arazi üzerine kurulmuştur. Çalışmaya konu olan inşaat projesi, İzmir Kemalpaşa Çiniliköy Mahallesi'nde $100.500 \mathrm{~m}^{2}$ arazi alanı üzerinde 67 blok olarak hayata geçirilmektedir. $45.000 \mathrm{~m}^{2}$ inşaat alanından oluşan projede, $3+1$ ve $5+1$ olmak üzere 4 farkıı türden 72 adet villa yer almaktadır. Alanları
$237 \mathrm{~m}^{2}$ ile $670 \mathrm{~m}^{2}$ arasında değişiklik gösteren villalarının konumları Şekil 2'de yer almaktadır.

Çalışma alanında, 1. Etap 26 adet dubleks bağımsız villa (A tipi $3+1$, B tipi $3+1$, C tipi bodrumlu $3+1$, D tipi bodrumlu 5+1) bulunmaktadır. Projede; A tipi villa 23 adet, B tipi villa 22 adet, C tipi villa 15 adet ve D tipi villa 12 adet olmak üzere toplam 72 adet villadan oluşmaktadır (Şekil 3).

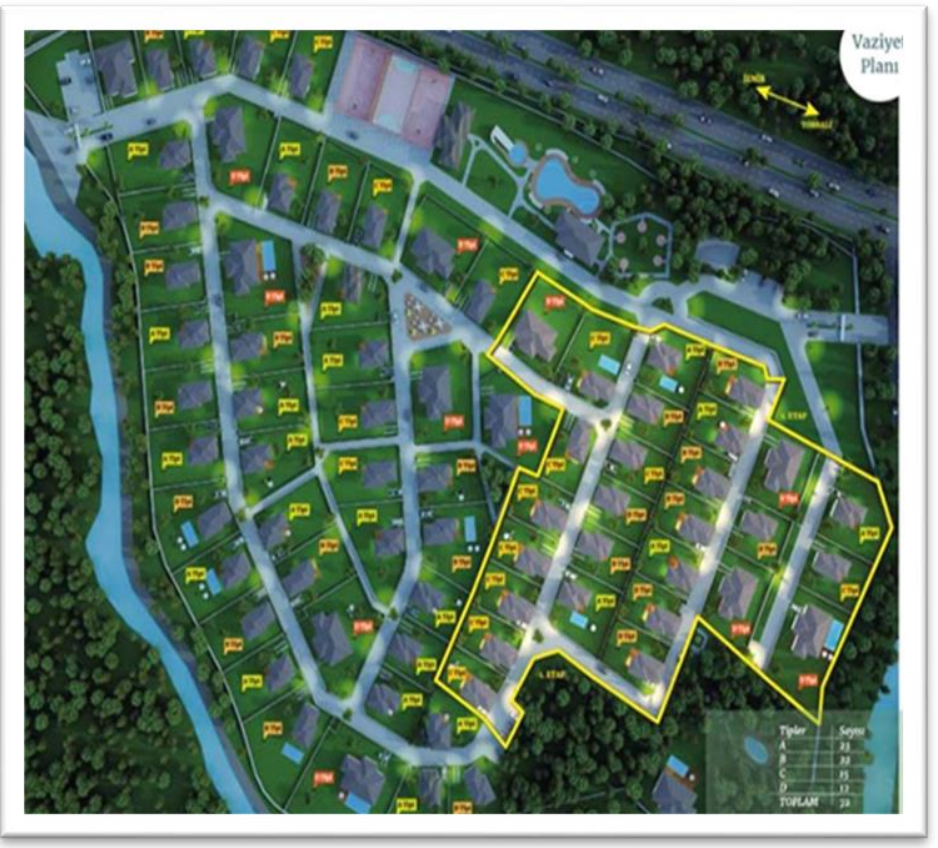

Şekil 2. Konut projesi vaziyet planı 


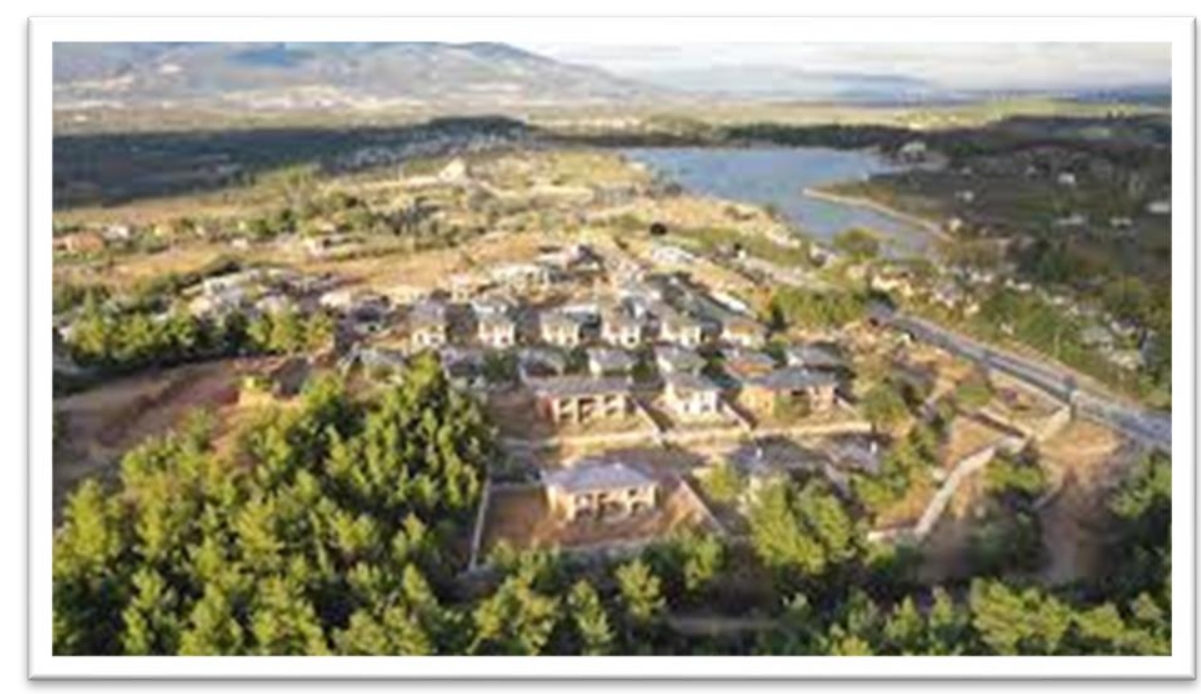

Şekil 3. Konut projesi şantiye alanı

Konut projesinde ortak kullanım alanlarındaki kullanımlar ayrı ayrı irdelenmiştir.

- Konut Projesinde Yollar: Site/Toplu konut bloklarını ve bütün tesisleri birbirine bağlayan ve sirkülasyonu sağlayan kısım yollardır. Alan içindeki ulaşım güvenli ve rahat olmalı, yaya ve motorlu araç yollarının ayırımı yapılmalıdır (Bekdemir, 2003).

Yaya yolları; eğim, yapıların engellemesi, iklim, bağlantı eksikliği hareketleri kısıtlayıcı ve yayaları zorlayıcı engellere karşı önlemler alınarak düzenlenmelidir. Eğimin fazla olduğu yerlerde, eğim yumuşatılmalı, olumsuz hava koşullarına yönelik ise arkatlar, yeşil ögeler, özel kentsel donatılar yapılarak engellenmelidir (Bakan ve Konuk, 1987).

Konut projesinin 1. etabında, site içi parke taş döşemesi uygulanan yolların tamamı proje üzerinde Şekil 4'te gösterilmektedir.

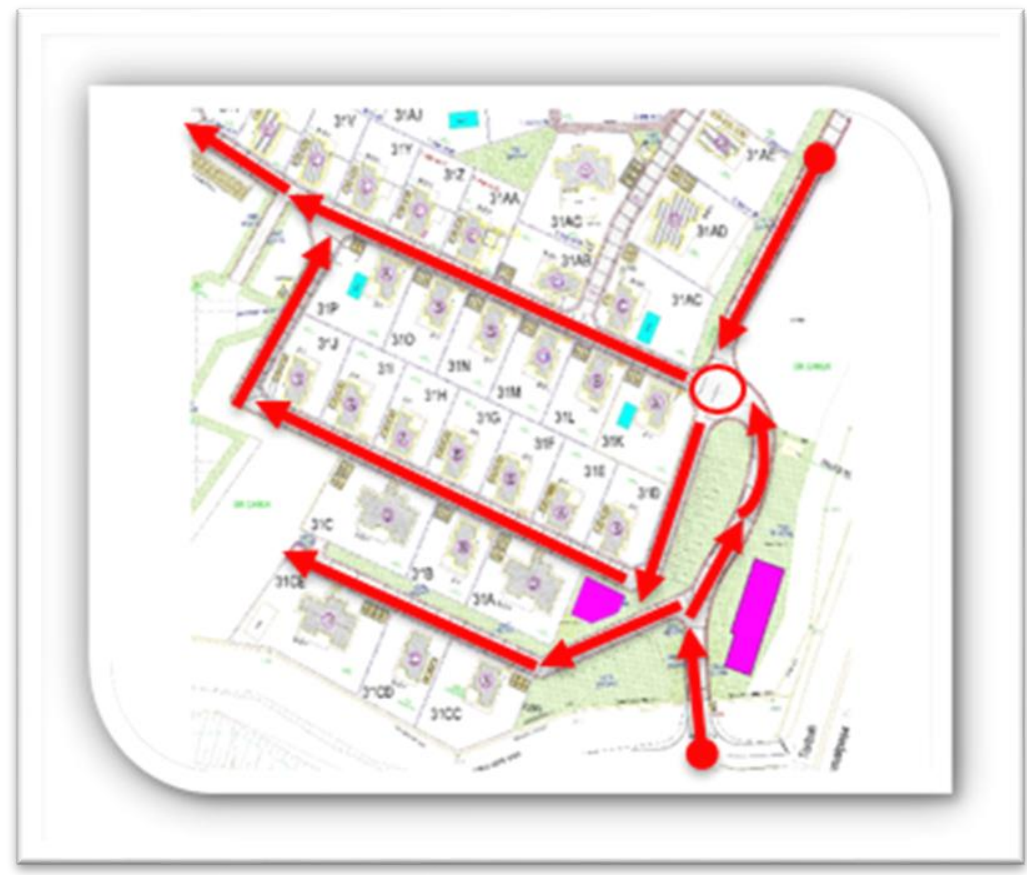

Şekil 4. Konut projesinde 1. etap site içi yollar 
Site içi yolarda, hem estetik bir görünüm sunması hem de özellikle eğimli yollarda su birikintisi yapmaması için alanda $10 \mathrm{~cm}^{*} 20 \mathrm{~cm}^{*} 6 \mathrm{~cm}$ ebatlarında gri ve siyah granül kaplamalı parke taşı kullanılmıştır (Şekil 5).
Söz konusu parke taşlarının döşemesi tamamlandıktan sonra, üst temizliği yapılarak döşeme uygulaması tamamlanmıştır. Ayrıca döşeme kenarlarında gerekli yerlerde bordür uygulaması da yapılmıştır (Şekil 6).
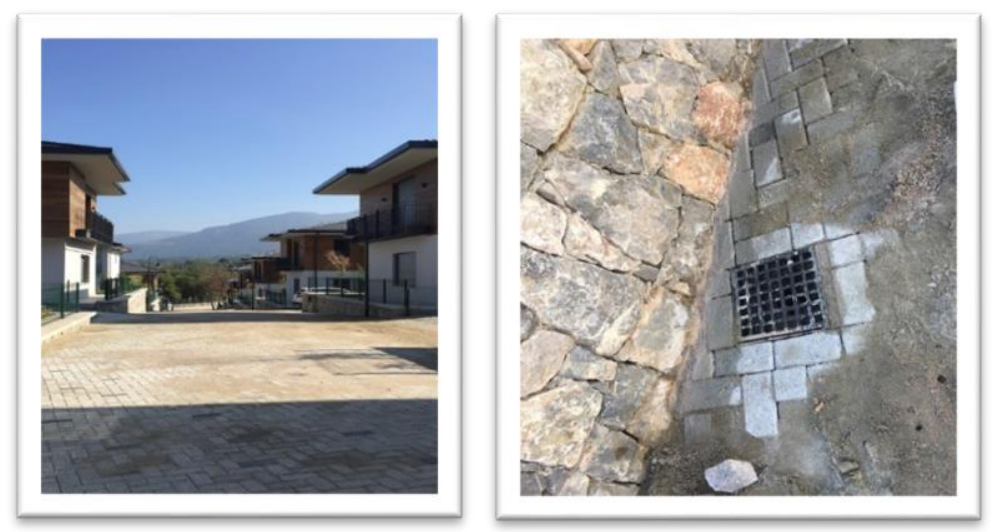

Şekil 5. Konut projesinde parke taşı uygulaması ve ızgara kullanımı
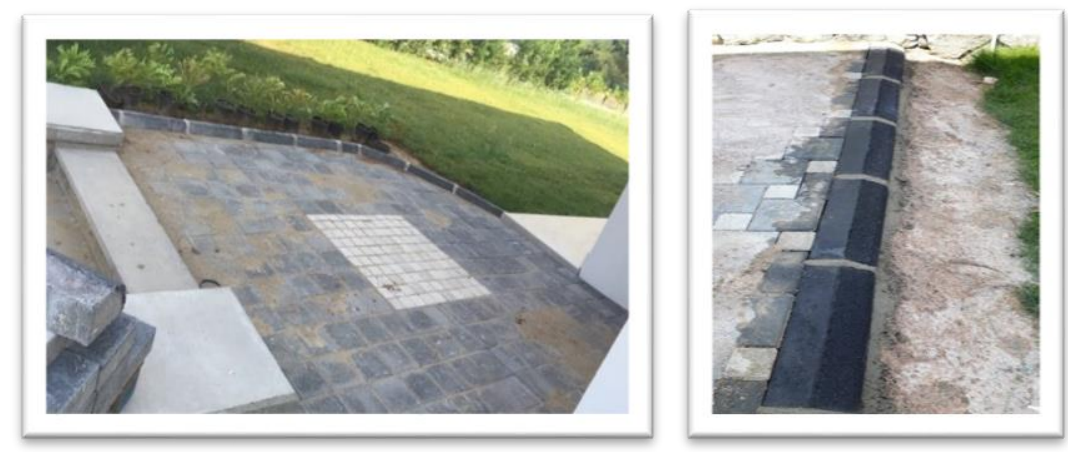

Şekil 6. Konut projesinde parke taşı ve bordür uygulaması

- Konut Projesinde Çocuk Oyun Alanları: Çocukların oyun oynayabilecekleri, sosyal ilişkilerini geliştirebilecekleri çocuk oyun alanları, taşıt trafiğinden uzak olarak tasarlanmalıdır. Aynı zamanda, aile bireylerinin birlikte gelecekleri dinlenme alanı olarak da düşünülmelidir. Çocuk oyun alanları (Bakan ve Konuk, 1987);

$\checkmark$ 0-4 yaş grubundaki çocuklar için; konuta çok yakın çim ve kum havuzlu alanlar,

$\checkmark$ 4-8 yaş grubundaki çocuklar için; konuttan izlenecek uzaklıkta, donanımlı oyun yeri ve

$\checkmark$ 8-12 yaş grubundaki çocuklar için; konut ile ilişkisi dolaylı, aletli oyun elemanları bulunan alanlardır.

Sitenin ortak kullanım alanında, çocuk oyun alanı da yer almaktadır (Şekil 7).
Çocuk oyun donatılarında, ahşap materyal ile plastik malzemenin birlikte kullanıldığı salıncak, kaydırak gibi donatılara yer verilmiştir (Şekil 8).

Çocuk oyun alanının çevresinde eğim bulunmaktadır. Bu eğimin çocuklar için tehlike oluşturmaması amacıyla, alanın etrafına çit amacıyla Alev çalısı (Photinia Red Robin) dikilmiştir. Ayrıca eğimli alanda çim yerine yer örtücü olarak, $20 \mathrm{~cm}$ dikim aralığı ile Acem halısı (Mesembryanthemum crinifolium) dikimi yapılmıştır. Ayrıca bu alanda damlama sulama sistemi uygulanmıştır. Eğimli alanın alt kısmında yer alan istinat duvarlarının bulunduğu kısma da $50 \mathrm{~cm}$ dikim aralığı ile Yıldız çalısı (Pittosporum tobira) dikimi yapılmıştır (Şekil 9). 


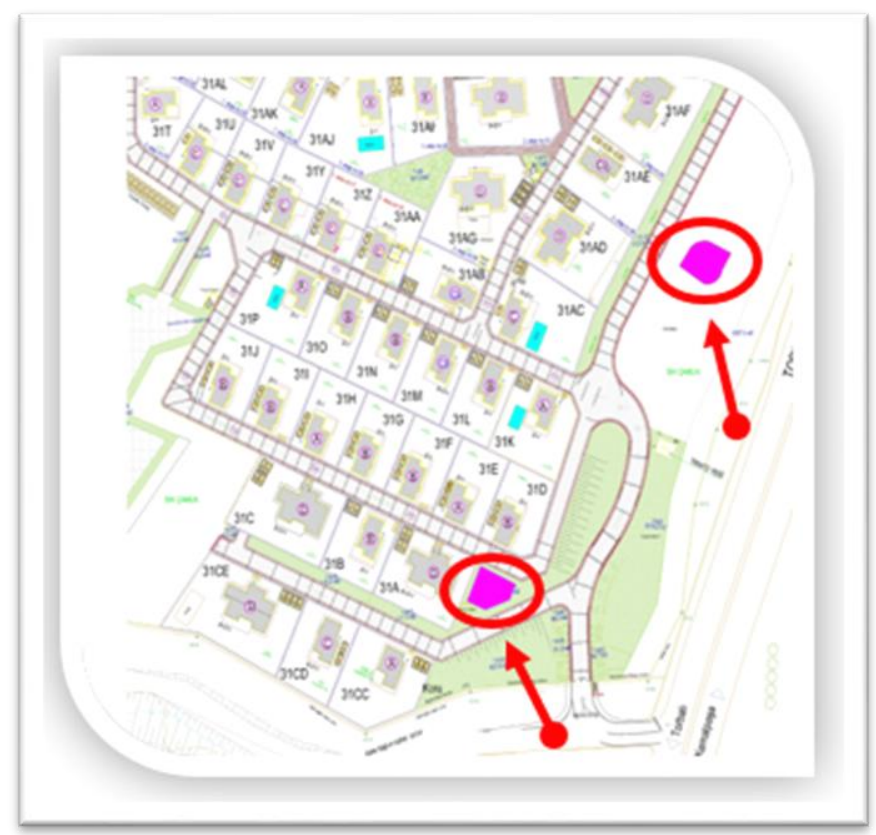

Şekil 7. Konut projesinde çocuk oyun alanlarının konumu
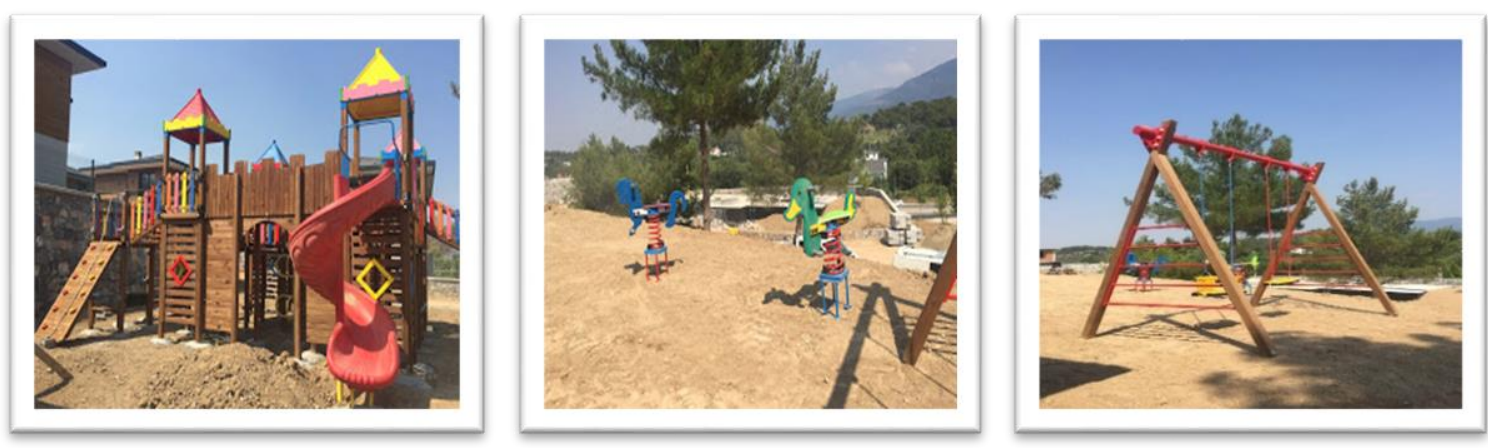

Şekil 8. Konut projesi çoçuk oyun alanında yer alan donatılar
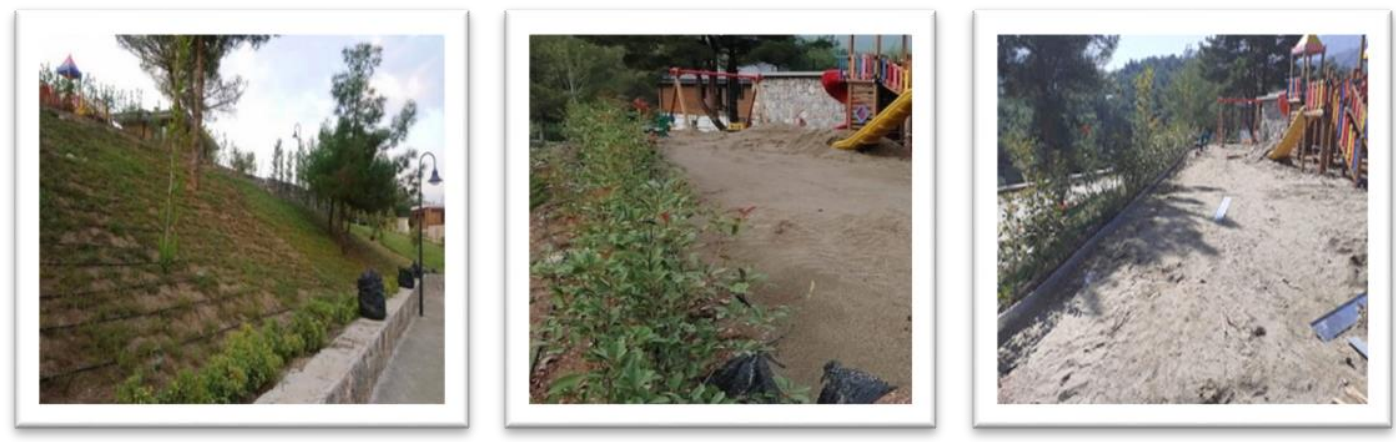

Şekil 9. Konut Projesinde çocuk oyun alanı ve çevresindeki bitkisel uygulamalar

Bitki dikimi yapılan kısım, alandan $18 \mathrm{~cm}$ yüksekliğinde galvaniz ayraç ile sınırlandırımış olup, kumun alan içinden dışarıya dağııması önlenmiştir (Şekil 10). 

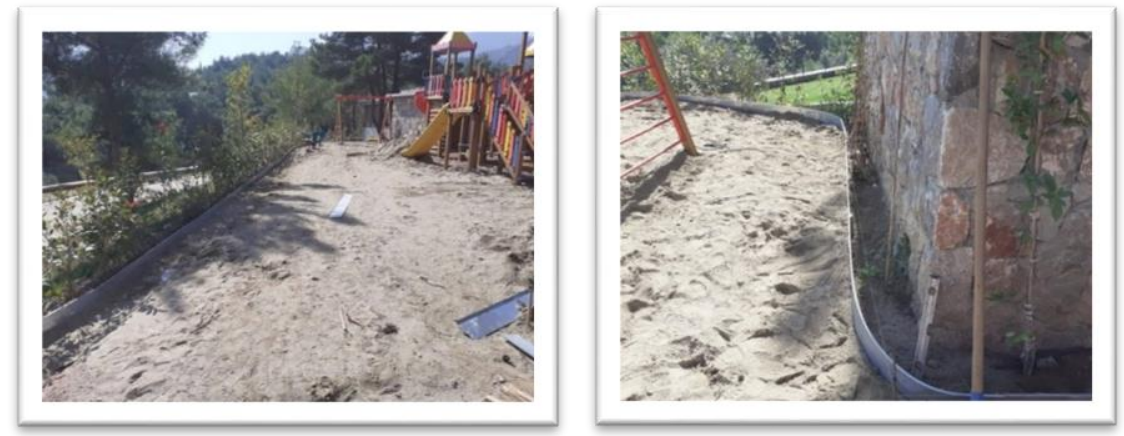

Şekil 10. Konut Projesinde çocuk oyun alanı çevre sınırlayıcı galvaniz ayraç uygulaması

Çocuk oyun alanında, yabani ot çıkmasını önlemek amacı ile toprağın üzerine jüt serimi yapılmış ve kazıklarla bu örtü yere sabitlenmiştir. Bu şekilde, oyun alanının zeminin doğal olması amaçlanmış ve kum kullanılmıştır.

- Konut Projesinde Otoparklar: Taşıtların park etmesi için düzenlenmiş ve ölçülendirilmiş alanlar olan otoparklar, toplu konut kullanıcılarının intiyaçlarına cevap verecek konum ve sayıda bulunmalıdır. Toplu konut uygulamalarında otopark intiyacının belirlenmesine yönelik kriterler aşağıdaki şekilde maddeler halinde vermek mümkündür (Bölen, 1987; Bakan ve Konuk, 1987; Beycan, 2004; Resmi Gazete, 2006):

Toplu konutlarda ikamet eden nüfusun $\% 0,5-\% 1^{\prime} \mathrm{i}$ için otopark yeri planlanmalıdır.

$\checkmark$ 22.04.2006 tarihli 26147 sayılı otopark yönetmeliğinde değişiklik yapılmasına dair yönetmeliğe göre; konutlarda ortalama daire brüt alanı $100 \mathrm{~m}^{2 \prime}$ ye kadar olan dairelerde 3 daireye 1 otopark, ortalama daire brüt alanı $150 \mathrm{~m}^{2}$ 'ye kadar olan dairelerde 2 daireye 1 otopark ve ortalama daire brüt alanı 150 $\mathrm{m}^{2}$ 'den büyük dairelerde ise 1 daire için 1 otopark yeri ayrılmalıdır. $\checkmark$ Otoparkların insan ölçeğinde tutulması amacıyla, en çok 5-7 araçlık gruplar halinde düzenlenmesi gereklidir. Çevrenin niteliğinin korunması amacıyla toplu konut alanlarında otoparklar parçalı çözümlenmelidir.

$\checkmark$ Taşıtların yanı sıra bisiklet ve motosiklet park yerleri de ayrılmalıdır. Bisiklet ve motosiklet park yeri için, 800 m² $^{2}$ den büyük otopark alanlarının \%20'si kadar alan ayrılmalıdır.

$\checkmark$ Otoparklarda yaya güvenliğini sağlamak ve yanlış park etmeyi önlemek için, otoparkların karşısına duvar veya sık ağaçlandırma yapıımalıdır.

Konut Projesinde, her konuta ait otopark bulunmaktadır. Otoparklar konut türlerine göre tek, iki ve üç araçlık otopark şeklinde değişiklik göstermektedir. Bunların yanısıra ortak kullanım alanlarında, misafir otoparkları da mevcuttur. Otopark döşemesinde, $(20 \mathrm{~cm} \times 20 \mathrm{~cm} \times 8 \mathrm{~cm})$ parke taşı kullanılmıştır. Konut projesinde uygulanan parke taş döşemesinde, konut girişi ve otoparklarda, stabilize malzemeden sonra kompaktör ile alanda zeminin sıkıştırılması sağlanmaktadır. Daha sonra parke taşlar alana döşenmekte ve üzerine taşların yerlerine oturması için tekrar kompaktör uygulaması yapılmaktadır. En sonunda parkelerin üzerine ince kum serilerek uygulama tamamlanmaktadır (Şekil 11).
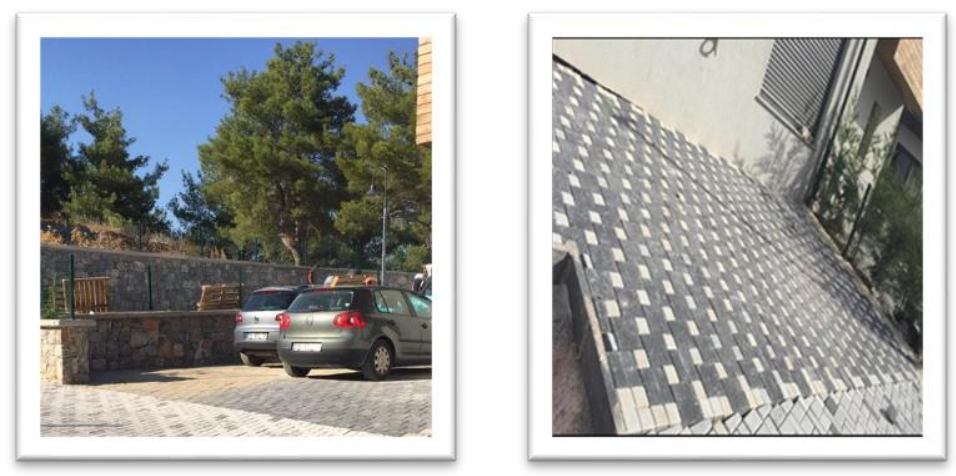

Şekil 11. Konut projesinde otoparklarda parke taş uygulaması 
- Konut Projesinde Yeşil Alanlar: Yeşil alanlar, site/toplu konutlarda dış mekan tasarımında önem verilmesi gereken faktörlerden birisidir. Bitkisel materyaller; seyretme, yaslanma, oturma, tırmanma, meyve gibi birçok işleviyle birlikte, rüzgâr ve güneşin olumsuz etkilerinden de korumaktadır. Ayrıca giriş belirleyici, yaya yollarında iz ve süreklilik oluşturma, sınırlandırıcı öğe, mekanda konum, mekana sınır ve yükseklik ge- tirme gibi dış mekanda bir tasarım öğesi olarak kullanılabilmektedir (Bakan ve Konuk, 1987).

Çalışma kapsamında, konut projesinde 26 konutta toplam 3.130 adet bitkisel materyal kullanılmıştır. Çalışma alanındaki konutların bahçelerinde Bermuda çim (Cynodon grass) ve 4 mevsim yeşil (Festuca arundinaccea, Lolium perenne, Poa pratensis) çim olarak iki çeşit çim türü kullanılmıştır (Şekil 12).

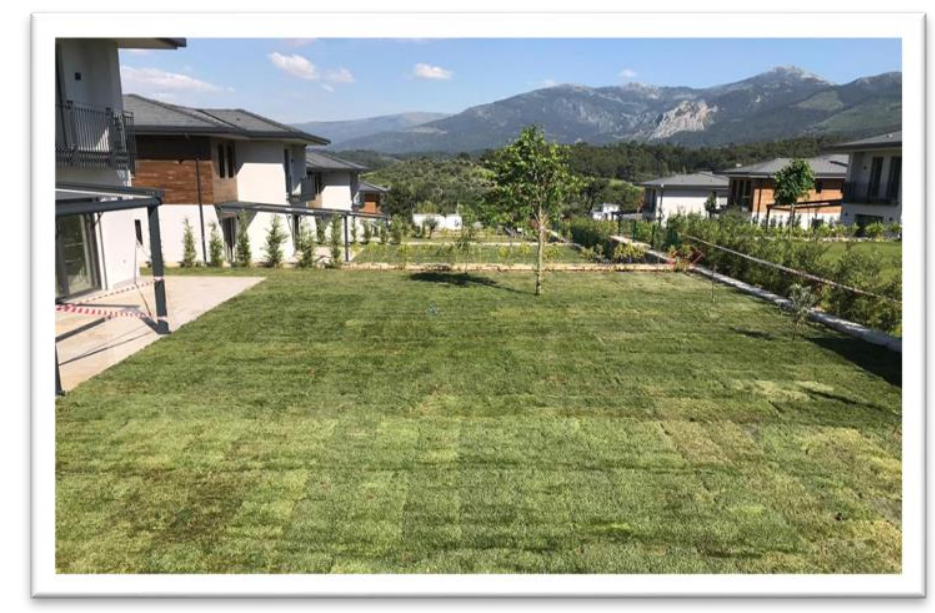

Şekil 12. Konut projesinde çim alan uygulaması

Bitki materyali olarak, proje kapsamında belirlenen ve peyzaj mimarlığı ilkelerine uygun bitkisel materyaller kullanılmıştır. Çalışma alanındaki bitkilerin seçiminde konuta ait bahçenin dışarıdan görülmesinin önüne geçilmiş ve bahçelerin belirli taraflarında bütün proje kapsamında özellikle çalı türleri kullanılmıştır. Konut bahçelerinin, site yollarına bakan taraflarında panel çit uygulaması yapılmış ve bu çitlerin kapatılması amacı ile sarılıcı-tırmanıcı türler seçilmiş ve uygulanmıştır. Bu türlerin seçiminde, çiçek renkleri ve koku özelliklerine dikkat edilmiştir.
Özellikle çiçek rengi mor ve beyaz olanlar tercih edilmiş olup, 1 beyaz ve 1 mor olmak üzere 1-26 nolu konutlara uygulama yapılmıştır. Ayrıca her bahçe için 1 adet ıhlamur ve 2 adet salkım söğüt ağacı dikilmiştir. Çalışma kapsamında temel peyzaj uygulaması yapılmış olup daha sonra konut sahibinin isteğine göre bahçelere bitkisel materyaller ilave edilmiştir. Çalışma alanında kullanılan bitki türleri ve adetleri Tablo 1'de yer almaktadır. 
Konut Bahçelerinde Peyzaj Uygulamaları Üzerine Bir Çalışma: İzmir İli Kemalpaşa İlçesi Örneği

Tablo 1. Konut Projesinde kullanılan bitki türleri ve adetleri

\begin{tabular}{|c|c|c|}
\hline Latince Adı & Türkçe Adı & Adet \\
\hline Abies fraseri & Köknar & 1 \\
\hline Acer negundo aureovariegatum & Alaca yapraklı akçaağaç & 1 \\
\hline Agapanthus africanus & Afrika zambağı & 3 \\
\hline Bougainvillea alexandra & Begonvil & 25 \\
\hline Buxus sempervirens & Top şimşir & 19 \\
\hline Carex morowii & Carex & 6 \\
\hline Chamaerops washingtonia & Palmiye & 3 \\
\hline Citrus lemon & Limon & 5 \\
\hline Cupressocyparis leylandii & Leylandii & 1.106 \\
\hline Cycas revoluta & Sikas & 1 \\
\hline Cydonia oblonge Miil. & Ayva & 3 \\
\hline Festuca glauca & Mavi çim & 38 \\
\hline Fortunella spp. & Kamkat & 1 \\
\hline Hydrangea macrophylla & Ortanca & 5 \\
\hline Jasminum sambac & Arap yasemini & 344 \\
\hline Juglans regia L. & Ceviz & 2 \\
\hline Lagerstroemia indica & Oya ağacı & 5 \\
\hline Laurus nobilis & Defne & 1 \\
\hline Lavandula officinalis & Lavanta & 3 \\
\hline Magnolia grandiflora & Beyaz çiçekli manolya & 1 \\
\hline Malus communis $\mathrm{L}$. & Elma & 6 \\
\hline Melissa officinalis & Melisa & 1 \\
\hline Morus nigra pendula & Ters dut & 1 \\
\hline Olea europaea bonsai & Zeytin Bonsaii & 8 \\
\hline Olea europaea & Zeytin & 3 \\
\hline Picea pungens & Mavi ladin & 1 \\
\hline Platanus orientalis & Doğu Çınarı & 2 \\
\hline Phormium tenax variegata & Alacalı formium & 6 \\
\hline Photinia Red Robin & Alev çalısı & 932 \\
\hline Prunus amygdalus Batsch. & Badem & 5 \\
\hline Prunus avium L. & Kiraz & 6 \\
\hline Prunus cerasifera Ehrh. & Yeşil Erik & 6 \\
\hline Prunus cerasus & Vişne & 3 \\
\hline Punica granatum & Nar & 6 \\
\hline Prunus persica & Nektari & 2 \\
\hline Pyrus communis L. & Armut & 3 \\
\hline Rosa spp. & Gül & 3 \\
\hline Salix babylonica & Salkım söğüt & 39 \\
\hline Syringa vulgaris & Leylak & 1 \\
\hline Tlia cordata & Ihlamur & 27 \\
\hline Viburnum lucidum & Kartopu & 278 \\
\hline Yucca massengena & Yukka & 1 \\
\hline Wisteria sinensis & Mor salkım & 217 \\
\hline
\end{tabular}

Çalışma alanındaki bitkisel uygulamalara ilişkin görseller Şekil 13 'te yer almaktadır. 

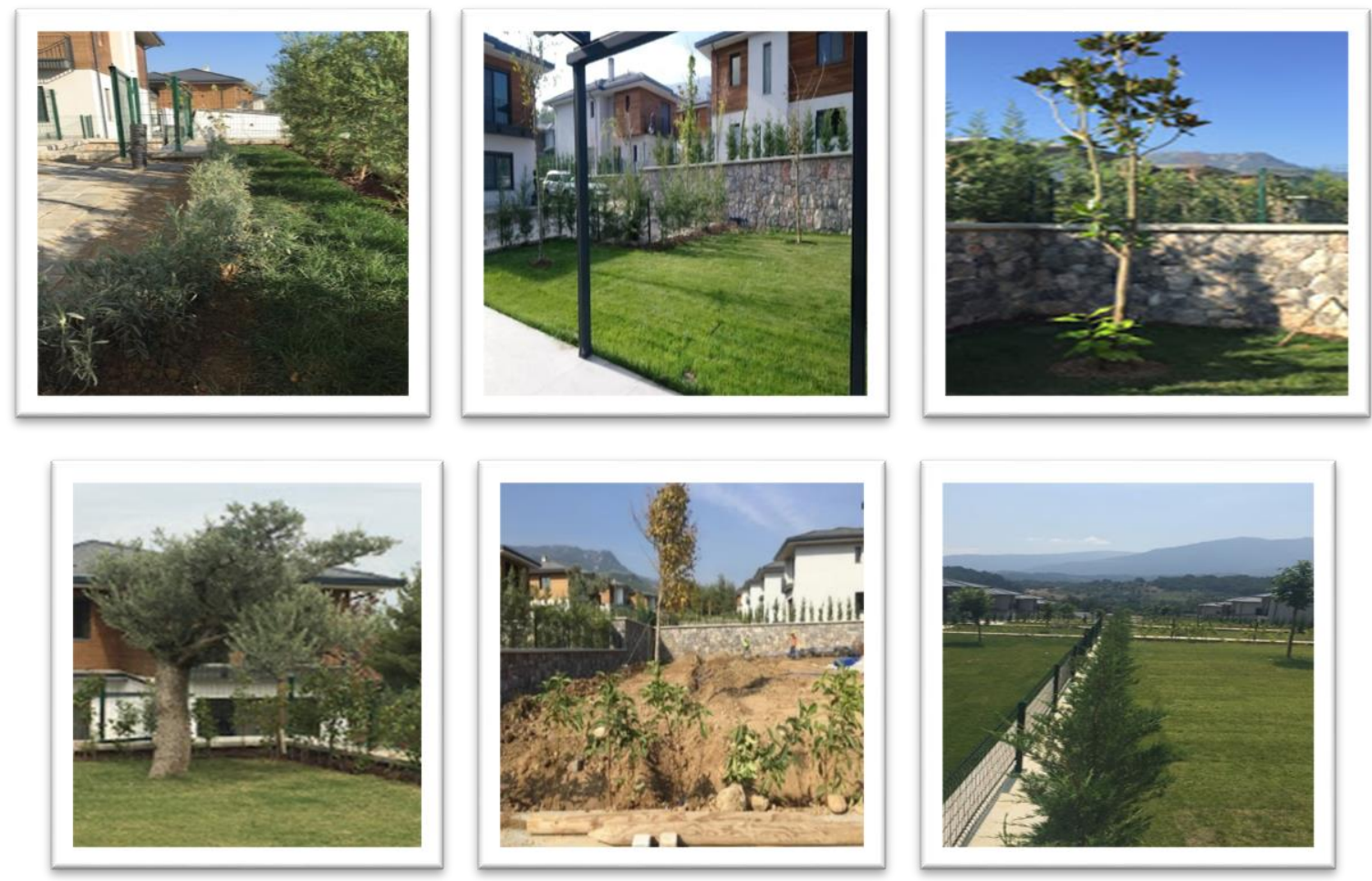

Şekil 13. Konut projesinde bahçelerde kullanılan bitkisel materyaller

- Konut Projesinde Spor Alanları: Basketbol, voleybol, futbol, tenis, okçuluk, atıcılık, golf vb alanlardır. Sporun cinsine göre farklı boyutlar kazanan bu alanlar, bulunması durumunda park ile bütünleşmelidir. Bu durumda, parkın işlevine yenilik katılarak kullanıcılara katkısı artacaktır (Bakan ve Konuk, 1987). Site/toplu konut yerleşimlerinde sosyo-kültürel bir değer taşıyan spor alanı olarak, 1. etap konutlarda tenis kortu, basketbol sahası ve açık yüzme havuzu yer almaktadır. Konutların yapımı tamamlanmış olmasına rağmen spor alanlarının yapımı henüz tamamlanmamıştır. Spor alanlarının yerleri Şekil 14'te yer almaktadır.

\section{SONUÇLAR}

Çalışma kapsamında, özel bir konut projesinde, alana özel peyzaj projesi hazırlanarak uygulaması yapılmıştır. Bu amaçla, peyzaj mimarlığı temel ilkeleri dikkate alına-

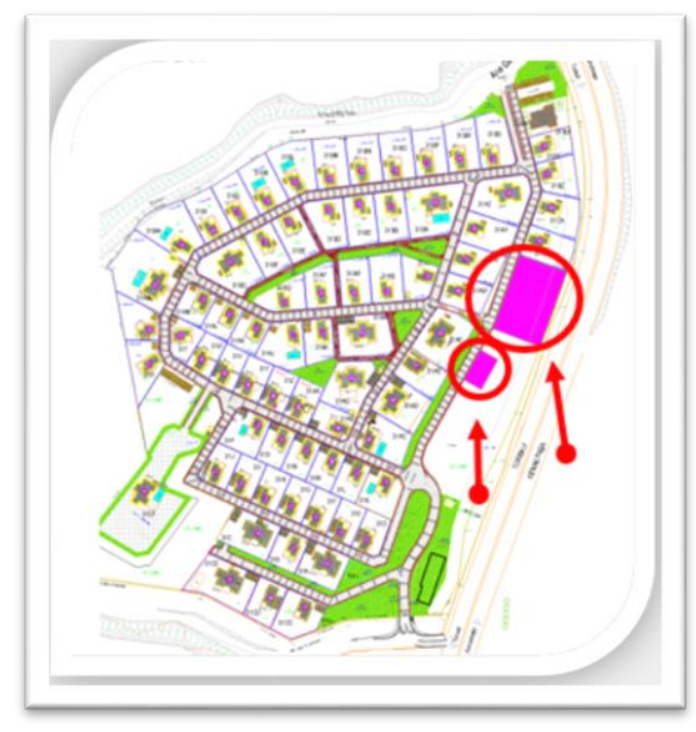

Şekil 14. Konut projesinde spor alanlarının konumu

rak veriler toplanmış, yerinde inceleme ve gözlemler sonucunda elde edilen girdi ve çıktılar biraraya getirilerek analiz ve değerlendirmeler yapılmıştır. Çalışma kapsamında alanda gözlemlenen durum, yapılan uygulamalar ve öneriler aşağıda özetlenmiştir: 
- Alan için hazırlanmış peyzaj projesinde, konut bahçelerinde süs bitkilerinin yanı sıra ceviz, kayısı, badem, kiraz, vişne, nar, şeftali, erik gibi meyve ağaçlarına ve lavanta, biberiye, kekik, adaçayı gibi tıbbi ve aromatik bitkilerin kullanılması önerilmiştir. Ayrıca bazı konut sahiplerinin talepleri doğrultusunda, sebze yetiştirmeye uygun alanlarda hobi bahçeleri oluşturulmuş ve bu bahçelerde domates, biber, salatalık, patlıcan, lahana, marul gibi sebzelerin yetiştirlebileceği şekilde düzenlenmiştir. Ayrıca estetik amaçlar kadar fonksiyonel açıdan da önem taşıyan çim alanları, konutlarının kullanıcılarının çoğunluğu tarafından tercih edilmiştir.

- Konut inşaat projesinde, konutlara ait açık alanlarda konut bahçesi dışında çocuk oyun alanına ve otoparklara yer verilmiş olmasına rağmen spor alanlarına, oturma-dinlenme alanlarına ve yeşil alanlara fazla yer verilmediği gözlemlenmiştir. Oysa toplu konutlarda/sitelerde ortak kullanım alanları, sosyal iletişim olanaklarının artırmasında oldukça önemlidir. Bu yüzden ortak kullanım alanlarında kullanılacak olan donatıların arttırılması ve daha fonksiyonel donatıların kullanılmasının tercih edilmesi gerekir.

- İnşaat alanında aydınlatma elemanlarının yeterli olmasına rağmen ikametin başladığı etap 1 için güvenlik görevlisinin olmaması, olumsuz etkiler oluşturabilir. Zira kullanıcılara rahat ve güvenli bir ortam sağlayan koruma hizmetinin sağlanmasıyla toplu konutlarda/sitelerde, sağlıklı yaşam çevreleri yaratılabilir.

- Büyük yerleşim alanlaında, sadece konutların yakın çevresinde dış mekanlarının var olması yeterli değildir. Bu alanların daha konforlu yaşanabilir olması, kullanıcıları çekebilmesi için bakım ve onarımının uzman elemanlar tarafından ve uygun şekilde yapılması, sürekliliğin sağlanabilmesi açısından oldukça önemlidir.

- Yaşanabilir yerleşimler yaratmak ve sürdürülebilirliği sağlamak için bilimin ve sanatın ışığında, var olan doğal ve kültürel kaynakları korumayı, geliştirmeyi, onarmayı ve uzun süre ve etkin biçimde tahrip etmeden yararlanmayı hedefleyerek açık ve yeşil alanların peyzaj planlama, tasarım, projelendirme, uygulama ve yönetimi sağlanması önemlidir.

- Konutların ve bahçelerinin kullanıcısı olan insanların, yaşadıkları mekânlarla ve o mekanların içinde bulundukları ekosistemlerle daha güçlü bir bağlantı kurabilmeleri için, söz konusu alanların tasarımında, en fazla söz sahibi olan kişiler olmalıdır. Bunun yolu da peyzaj tasarımındaki her detayın, bir uzmanla yani peyzaj mimarı ile birlikte üzerinden geçilmesi ve uzlaşılması gerekir.
Sonuç olarak, çalışma alanı olarak seçilen özel bir konut inşaat projesinin hem proje aşamasında hem de uygulama aşamasında peyzaj mimarları ile çalışılmış olması bir avantajdır. Ekolojik, fonksiyonel, ekonomik ve sürdürülebilirlik gibi temel tasarım ilkeleri çerçevesinde, toplum yapısının gelişimine katkı sağlayan bu çalışmanın diğer şehirlerde ve ilçelerde de yapılacak çalışmalara örnek olması beklenmektedir.

\section{KAYNAKLAR}

Akdoğan, G. (1995). Dünden bugüne bahçe kültürümüz. Bahçe Kültürü Dergisi, 58: 7-14.

Amerigo, M., Aragones, J.I. (1990). Residential satisfaction in council housing. Journal of Environmental Psychology, 10(4): 313-325.

Bakan, K., Konuk, G. (1987). Türkiye'de kentsel dış mekânların düzenlenmesi. TÜBITAK Yapı Araştırma Enstitüsü Yayınları, 104 s., Ankara.

Baker, E. (2003). Public Housing Tenant Relocation: Residental Mobility, Satisfaction and The Development of A Tenant's Spatial Decision Support System, Ph. D. Thesis, The Adelaide University Department of Geographical and Environmental Studies, Adelaide, Australia.

Bayraktar, N., Girgin, Ç. (2010). Kooperatif üst birlikleri tarafından gerçekleştirilen konut yaşam çevrelerinde kentsel yaşam kalitesi açısından bir değerlendirme/Batıkent örneği. Gazi Üniversitesi. Mühendislik Mimarlık Fakültesi Dergisi, 25(2): 201-211.

Bekdemir, A. P. (2003). İstanbul-Bahçeşehir Toplu Konut Yerleşmesinde Dış Mekan Kullanım Olanaklarının İrdelenmesi, Yüksek Lisans Tezi, İstanbul Üniversitesi, Fen Bilimleri Enstitüsü, İstanbul.

Beycan, Ş. (2004). Çanakkale'de Kamu Eli ile Üretilmiş Toplu Konutların Mekansal, Alansal ve Boyutsal Analizleri ve Üretim Sistemleri Üzerine Bir İnceleme, Yüksek Lisans Tezi, Yıldız Teknik Üniversitesi, Fen Bilimleri Enstitüsü, İstanbul.

Bölen, F. (1987). Konut-otopark ilişkisi, Toplu Konutlarda Mekan Standartları Paneli, Yapı-Endüstri Merkezi, 178-183, İstanbul.

Conan, M. (2006). Methods and perspectives for the study of gardens and their reception, gardens and ımagination: cultural history and agency ed. Micheal Conan, Dumbarton Oaks Research Library and Collection, Harvard University Press, 3- 17.

Çetinkaya, A. (2016). Profesyoneller İçin Ev Bahçeleri Tasarım ilkeleri. https://www.plantdergisi.com/abdurrahman-cetinkaya/profesyoneller-icin-ev-bahceleri-tasarim-ilkeleri.html (Erişim Tarihi:25.12.2019).

Demirarslan, S. (2005). Türk insanı için yapılan konutlarda yaşam kalitesinin elde edilebilmesi için gerekli faktörler. Konut Değerlendirme Sempozyumu 2004, ITÜ Mimarlık Fakültesi Yayınları, İstanbul.

Dülgeroğlu, Y.Y. (1995). Konut kavramının tipolojik temelleri. ITÜ Yayınları, İstanbul.

Fernandez, G.F.M., Pèrez, F.R., Abuín, J.M.R. (2003). Components of the residential environment and socio-demographic characteristics of the elderly. Journal of Housing for the Elderly, 18(1): 25-49. 
Konut Bahçelerinde Peyzaj Uygulamaları Üzerine Bir Çalışma: İzmir İli Kemalpaşa İlçesi Örneği

Gültekin, E. (1991). Bahçe ve sanat tarihi. Çukurova Üniversitesi Ziraat Fakültesi Ders Kitabı, No:94, Ç.Ü. Ziraat Fakültesi Ofset ve Teksir Atölyesi, Adana.

Gökçe, Ş. (2007). Sosyal etkileşimi geliştirecek peyzaj tasarımı üzerine bir araştırma: Çukurambar Mahallesi örneği. Yüksek Lisans Tezi, Ankara Üniversitesi Fen Bilimleri Enstitüsü Peyzaj Mimarlığı Anabilim Dalı, 149 s.

Hayward, G. (1975). Home as an environmental and psychological concept. Landscape, 20.

Karaçizmeli, E.B. (2011). Gelenekselden Küresele Bahçe Tasarımı: Çin ve Japonya'dan Örnekler. Yüksek Lisans Tezi, İstanbul Teknik Üniversitesi Fen Bilimleri Enstitüsü, Peyzaj Mimarlığı Anabilim Dalı, İstanbul.156 s.

Korkut, A.B. (2002). Peyzaj Mimarlığı. Hasad Yayıncılık Ltd. Şti., 167s, İstanbul.

Kumbasar, S.B. (2008). Konut Gelişiminde Gelecek Vizyonları. Yüksek lisans tezi, Yıldız Teknik Üniversitesi, Fen Bilimleri Enstitüsü, Mimarlık Anabilim Dalı, İstanbul.

Lang, J. (1994). Urban design. The Amerikan Experience, Van Nostrand Reinhold, New York.

Resmî Gazete (2006). Otopark Yönetmeliğinde Değişiklik Yapılmasına Dair Yönetmelik, Madde 5, Başbakanlık Mevzuatı Geliştirme ve Yayın Genel Müdürlüğü, Ankara.

Özdemir, L. (2006). Karabük İli Beşbinevler Toplu Konut Alanında Konut Açık ve Yeşil Alan İlişkisinin İrdelenmesi. Yüksek Lisans Tezi, Zonguldak Karaelmas Üniversitesi Fen Bilimleri Enstitüsü, Peyzaj Mimarlığı Anabilim Dalı, Bartın, $122 \mathrm{~s}$.
Rapoport, A. (1969). House form and culture. Prentice Hall International, London.

Subaşı, B. (2000). İzmir İli Gaziemir İlçesi Örneğindeki Uygulamalarda Toplu Konut Açık Alanlarının Peyzaj Mimarlığı İlkeleri Çerçevesinde İrdelenmesi. Yüksek Lisans Tezi, Ege Üniversitesi Fen Bilimleri Enstitüsü, Peyzaj Mimarlığı Anabilim Dalı, İzmir, $75 \mathrm{~s}$.

Tanrıverdi, F. (1975). Peyzaj mimarisi bahçe sanatının temel prensipleri ve uygulama metodları. Atatürk Üniversitesi Yayınları No:148, Ziraat Fakültesi yayınları No: 196. Sevinç Matbaası, Ankara.

Taşkan. G. (2014). Bartın Kenti Geleneksel Konutlarındaki Yapısal Değişimlerin Bahçe Mekânı ve Kullanılan Bitki Materyaline Yansımaları. Bartın Üniversitesi Fen Bilimleri Enstitüsü, Peyzaj Mimarlığı Anabilim Dalı, Yüksek Lisans Tezi. Bartın.

Türkoğlu, H. (1997). Residents' satisfaction of housing environments: The case of Istanbul, Turkey. Landscape and Urban Planning, 39: 55-67.

URL-1 (2019). https://www.academia.edu/217286/Ev_Bah\%C3\%A7eleri_Tasar\%C4\% B1m_ve_Planlama_\%C4\%BOlkeleri (Erişim Tarihi: 25.12.2019)

URL-2 (2020). https: //cimdunyasi.com.tr (Erişim Tarihi: $17.10 .2020)$

URL-3 (2020). https: //tr.m.wikipedia.org (Erişim Tarihi: 29.11.2020)

URL-4 (2020). http://www.yardimcikaynaklar.com/izmir-yuzeysekilleri-ve-iklimsartlari (Erişim Tarihi: 30.11.2020) 